\title{
The contribution of resources and capabilities to the competitiveness: The case of Port of Sines
}

\author{
Susana Garrido Azevedo, João Ferreira \\ (Department of Management and Economics, University of Beira Interior, Covilhã 6200-209, Portugal)
}

\begin{abstract}
The main objective of this paper is to analyse the competitiveness of the main maritime Port sited in Portugal - Port of Sines. This paper is developed under the resource-based view approach. A literature review about the resource-based view is presented with a special highlight on the contribution of organisation owns' resources to the competitiveness. With this study we intend to emphasize the applicability of a management theory to a different type of organisation which only recently starts to be preoccupied with its competitiveness. A case study methodology is used in order to collect all information needed about its main resources and capabilities of Port and also its competitiveness. The resources analysed in this paper are: The infrastructures, the accessibilities, the Port operations and also the information systems used on it. Also, a set of performance data is analysed as the main indicators of competitiveness. After that, a conceptual model is presented in order to systematise the main resources and capabilities under which the competitiveness of the Port of Sines is built on.
\end{abstract}

Key words: competitiveness; sea Port; resource-based view; case study

\section{Introduction}

Understanding sources of sustained competitive advantage for firms has become a major area of research in the field of strategic management (Wernerfelt, 1989; Porter, 1985; Barney, 1991; Grant, 1991). The main objective of this paper is to analyse the competitiveness of the Port of Sines according to the Resource-Based View (RBV). The Port of Sines is described as regards its main characteristics, its main resources and also its performance during the last years. After that a conceptual model is proposed to highlight the main resources over which its competitiveness is built.

Methodologically it used the case study and the data to develop this study was obtained from strategic planning and statistics reports of the port, which is accessible on Port's website. This paper is organised in the following way: First the RBV is presented, second the main characteristics of the Port of Sines are described and third the main resources and capabilities are pointed out. Finally, the key performance data is presented and the conclusions are drawn.

\section{The resource-based view}

The most salient characteristic of the RVB is focus in the internal forces of firm. This approach is rather

Susana Garrido Azevedo, Ph.D. in management, Department of Management and Economics, University of Beira Interior; research fields: supply chain management, logistics.

João Ferreira, Ph.D. in management, Department of Management and Economics, University of Beira Interior; research fields: entrepreneurship and strategy. 
linked to the pioneering work of Penrose (1959) than any other. Recently there has been a reinforced interest in role of firm resources as foundation for firm strategy (Grant, 1991; Miller \& Shamsie, 1996). This interest reflects some dissatisfaction with the static, equilibrium framework of industrial organisation economics, where the focus was in the relationship between the strategy and the external environment (Grant, 1991). Several advances have occurred on different strategic levels and all of them contributed to what has been termed resources-based view. Basically, RBV describes a firm in terms of the resources that firm integrates. Penrose (1959) accentuates the condition of a firm not be just a unit, but also a group of resources. Frequently, the term resource is limited to those attributes that enhance efficiency and effectiveness of the firm (Wernerfelt, 1984). Miller and Shamsie (1996) refer that resources should have some capability to generate profits or to avoid losses. A general resources' availability it will neutralize the firm' competitive advantage. Once, for a firm to take high levels of performance and a sustained competitive advantage, it needs to acquire heterogeneous resources which will be difficult to create, substitute or imitate by other firms.

According to Penrose (1959), Wernerfelt (1984) and Rumelt (1991), a firm is a compilation of productive, tangible and intangible resources, assembled in a tool of administrative job. In this sense, this theory defends that, under imperfection of markets exists a diversity of firms and a variation in the specialisation degrees that provokes a limited transfer of resources which present type, magnitude and different nature (Amit \& Schoemaker, 1993). Therefore, the main reason for firms grow and have success can be found inside of the firms, that is, firms with resources and superior capabilities will build up a basis for gaining and sustaining competitive advantage (Peteraf, 1993).

Several authors (Lippman \& Rumelt, 1982; Jacobsen, 1988; Day \& Wensley, 1988; Grant, 1991; Barney, 1991; Rumelt, 1991; Amit \& Schoemaker, 1993; Day, 1994) when referring to the RBV, they do it more in a strategic context, presenting resources and capabilities as essential to gaining a sustained competitive advantage and, consequently, to a superior performance. However, these resources must have some characteristics, namely: (1) specialized (Barney, 1986; Dierickx \& Cool, 1989, 1990; Amit \& Schoemaker, 1993); (2) scarces (Barney, 1986; Dierickx \& Cool, 1989; Barney, 1991; Amit \& Schoemaker, 1993; Day, 1994, 1990; Skjoett-Larsen, 1999); (3) durables (Grant, 1991); (4) hard to trade (Barney, 1986; Dierickx \& Cool, 1989, 1990; Amit \& Schoemaker, 1993; Skjoett-Larsen, 1999); (5) costly to copy (Barney, 1991; Amit \& Schoemaker, 1993); and (6) valuables (Barney, 1991, Day, 1994; Skjoett-Larsen, 1999).

Learned, et al (1969), Wernerfelt (1984), and Porter (1985) adopted RBV from a strategic point of view considering a resource as a strength that firms can use to formulate and to implement their strategies. The resources and capabilities of the firm are the main competences for formulating strategy (Grant, 1991).

Some authors (Barney, 1991; Grant, 1991; Mahoney \& Pandian, 1992; Day, 1994; Chandler \& Hanks, 1994) enhance that resources are insufficient for obtaining a sustained competitive advantage and a high performance well. According to them, this is possible only if the firms are able to transform resources in capabilities, and consequently in a positive performance (Mahoney \& Pandian, 1992). Penrose (1959) refers that the firms reach a superior performance, not only because they have more or better resources, but also because of their distinctive competences (those activities that a particular firm does better than any competing firms) allow to do better use of them.

Despite the wide diversity of resources, it is possible to classify it according to following categories: (1) tangible and intangible resources (Penrose, 1959; Hall, 1992; Amit \& Schoemaker, 1993; Bogaert, et al., 1994); (2) strategic resources (Day \& Wensley, 1988; Day, 1994); (3) human resources (Greene, et al., 1997); (4) social 
resources (Greene, et al., 1997); (5) organizational resources (Greene, et al., 1997); (6) technological resources (Greene, et al., 1997); (7) location resources (Greene, et al., 1997); (8) factor conditions (Olavarrieta \& Ellinger, 1997; Day, 1994; Grant, 1991; Barney, 1991); (9) assets (Barney, 1991; Amit \& Schoemaker, 1993; Day, 1994); and (10) capabilities (Barney, 1991; Amit \& Schoemaker, 1993; Day, 1994).

Regarding the capabilities, they are considered, for some authors, not only as firm's resources but also as competences (Penrose, 1959; Hitt \& Ireland, 1986; Prahalad \& Hamel, 1990; Pavitt, 1991; Leonard-Barton, 1992) and invisible assets (Itami, 1987). The concept of capabilities is frequently used to define a group of individual qualifications, assets and accumulated knowledge, exercised through organizational processes allowing to coordinate activities and to use their resources (Amit \& Schoemaker, 1993; Day, 1994; Schulze, 1994).

According to Grant (1991) there is a key distinction between resources and capabilities. Resources are inputs into the production process-they are the basic units of analysis. The individual resources of the firm include items of capital equipment, intellectual assets, patents, brand names, and so on. A capability is the capacity for a team of resources to perform some task or activity. While resources are the source of the firm's capabilities, capabilities are the main source of its competitive advantage. For Barney (2001) these distinctions can be drawn in theory, but quite confused in practice. The capabilities are many times developed either in functional areas or in combination of physical, humans or technological resources, controlled by the firm (Amit \& Schoemaker, 1993). Capabilities together with the resources are the core competences on firm's strategy formulation and therefore constitute the firm’s identity (Grant, 1991).

In fact, as refer Bogaert, et al (1994) how more capability is used, more it can be refined and more hard is to copy. This characteristic reflects the dynamic perspective associated to the capabilities (Nelson, 1991). In the dynamic perspective, capabilities approach is a theoretical stream inside of the RBV. This theory considers that, on one side, the firms are constantly creating new combinations of capabilities and, on other hand; the market competitors are continually improving their competences or imitating the most qualified competences from other firms. This approach puts emphasis on internal processes, assets, market position as restricting factors not only the capability to react but also the management capability to coordinating internal competences of the firms (Teece \& Pisano, 1994).

In addition, some authors Granstrand, et al (1997) give special attention to technological competences as an important factor to influence, not only the sales' growth, but also the businesses' diversification and performance. According to Grant (1991) the managers must select an appropriate strategy in order to use more effectively the resources and the capabilities of the firms. In this sense, it is pointed out the following question: what extent the resources and the central capabilities are identified and applied in a strategic way to create a competitive advantage? Barney (2001) developed the VRIO model structured in a series of four questions to be asked about the business activities a firm engages in: (1) the question of Values; (2) the question of Rarity; (3) the question of Imitability; and (4) the question of organization. The answers to these questions determine whether a particular firm resource or capability is a strength or weakness. The VRIO model describes ways that firms can expect to be successful.

Competitive value of the resources can be enhanced or annulled by changes in the technology, by changes in the competitor's behaviour, or by changes in the buyers' needs. All these aspects would be neglectful whether the analysis focus was only centred in the internal resources (Porter, 1985). According to Chandler and Hanks (1994) resources and capabilities create a satisfactory base for formulating competitive strategies. An important factor that assures a long term competitive advantage is the sustainability of the firm's capabilities or their core 
competences (Chandler \& Hanks, 1994; Aliouat, 1999). Sustained capabilities are those that are not easy or quickly reproduced by the competitors and must form the base of firm's strategy. These resources and capabilities are the key for the achievement of competitive advantage and should be protected. Being so, they have a critical role in the competitive strategy of an organisation in general and in an organization with the ports' characteristics in particular.

\section{Port of Sines}

\subsection{General characteristics}

The Port of Sines is an open deep-water seaport with excellent maritime convenient, without restrictions, leading the Portuguese Port sector in the volume of cargo handled, and offering unique natural characteristics to receive any type of vessels. This is one of the main characteristic that contributes to the competitiveness of the Port of Sines (Tongzon, 2007) since to accommodate trade growth and to offer economies of scale in a highly competitive market, many shipping companies intend to increase the size of their container ships which will imply a larger vessels and consequently deeper waters. Due to its modern specialized terminals, the Port is able to handle the different types of cargoes.

The Port of Sines is the main Port in the Ibero-atlantic front, whose geophysical characteristics have been determinant on its consolidation as a strategic national active. It is the country's leading energetic supplier (crude and its derivatives, coal and natural gas), as well as an important Port as far as general and containerized cargo concerns, presenting a high growth potential, in order to become a reference Port at an Iberian, European and worldwide level. The general and dry bulk cargo to the regional market offers a great opportunity as far as the Multipurpose Terminal exploitation concerns (Fig. 1).

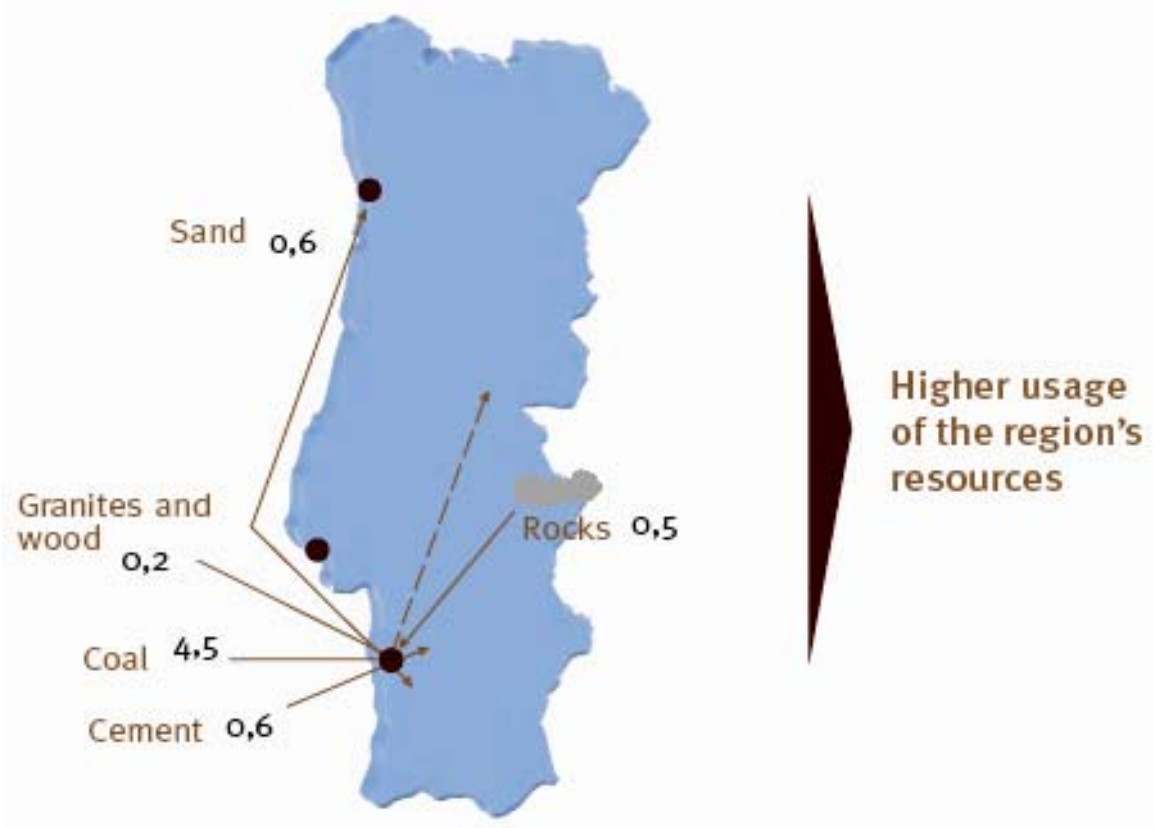

Fig. 1 Main cargo in Port of Sines

Data source: Port of Sines strategic plan (2003, p. 29). 
The Port of Sines is located on the Southeast of Europe, 58 nautical miles south from Lisbon, on the cross of the main international maritime routes - East-West and North-South. Its strategic location, along with its natural characteristics, allows the Port to be positioned as the great hub Port of the Ibero-Atlantic front (Fig. 2). Its direct hinterland comprises all the south and midland part of Portugal and reaching a competitive position also in Spain.

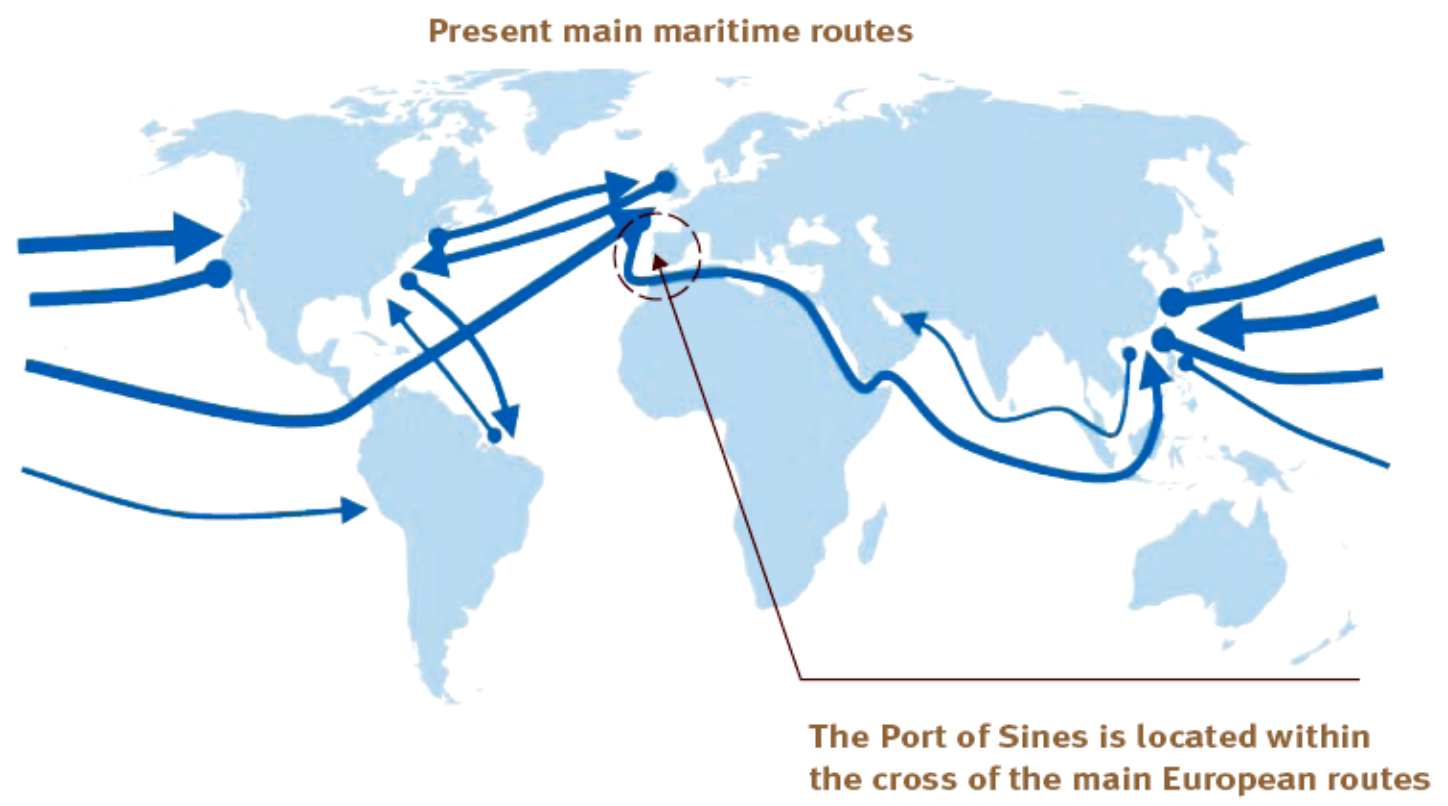

Fig. 2 Port of Sines localization

Data source: Port of Sines strategic plan (2003, p. 13).

\subsection{Main resources at the port}

\subsubsection{Infrastructures}

According to Marlow and Casaca (2003) more than ever it is important that ports are agile. In this sense, ports require a set of infrastructures in a logic of just-in-time and lean logistics to become the operations more efficient and cheaper. The same authors highlight the existence of different modes of transport, a special port layout for entry and exit of cargoes with all the several port infrastructures and superstructure requirements.

The Port of Sines and its support Industrial and Logistics Zone, with more than 2,000 ha., are already a worldwide extent logistic platform, able to receive the main players of Port, maritime, industrial and logistic sectors. The Sines Logistics Platform combines a modern international deepwater Port with a major Industrial and Logistics Zone (ZILS). This publicly managed zone has over 2,000 hectares available for the use of industrial companies and related service providers. The Port of Sines has the Zalsines. This is a modern logistical platform with high strategic potential for value added services. It is settled in a vast area with logistical capability, with plots of land available, and being developed in a flexible and staged manner. It is geared towards the installation of industrial and service companies, serviced by a road and rail system with large capacity and as part of the main multimodal axes of the Trans-European Transport Networks.

The land allocated to the development of the ZAL at Sines covers two areas: one situated in the intra-Port zone and the other one in the extra-Port zone. It has a liquid bulk terminal, designed according to a multi-client and multi-product architecture. This bulk has six jetties and natural beds down to 28 metres ZH, has the capacity 
to receive vessels up to 350,000 tonnes Dwt, and allows the simultaneous handling of different products (crude, refined products, liquefied gases and other liquid bulks).

Port of Sines has also a network of pipelines for moving products between the Port, the adjoining tanking area and the Sines industrial logistics area where the main industries are located which use the terminal (refinery, petrochemicals, resins factory and carbon black smoke factory). The terminal operates under a public service cargo handling regime, being directly operated by APS. In order to meet what is set out in the Strategic Plan for the Port of Sines and the guidelines of the responsible authorities, the process is ongoing vis-à-vis the concession of this service and is expected to be completed on January 1st, 2008.

The terminal is equipped with a modern computerized command and control system which allows compliance with the highest safety standards in the operations carried out. It is also associated with waste and ballast water treatment plant which allows compliance with all environmental requirements. The Liquid Bulk Terminal (TGLS) also has a good capacity for expansion and is able to receive new clients who wish to set up in the tanking area or in the ZILS. This terminal is endowed with a fuelling bunkering facility also, managed by Galp Marinha and Aviação which allows the supplying of ships at the TGLS through a fixed installation and throughout the Port by barge.

\subsubsection{Accessibility}

The Port of Sines offers excellent maritime accessibility, with no restriction in terms of depth (natural sea bottoms with no need to dredging), providing unique conditions for the reception of large vessels. This is one characteristic that contributes to the competitiveness of the port of Sines (Tongzon, 2007). This open sea Port is sheltered by two breakwaters - West Breakwater (2,000 m N-S orientation) and the East Breakwater (2,200 m NW-SE orientation). The Port of Sines is sited in a strategic geographic location since it is near the main maritime intersections (Fig. 3).

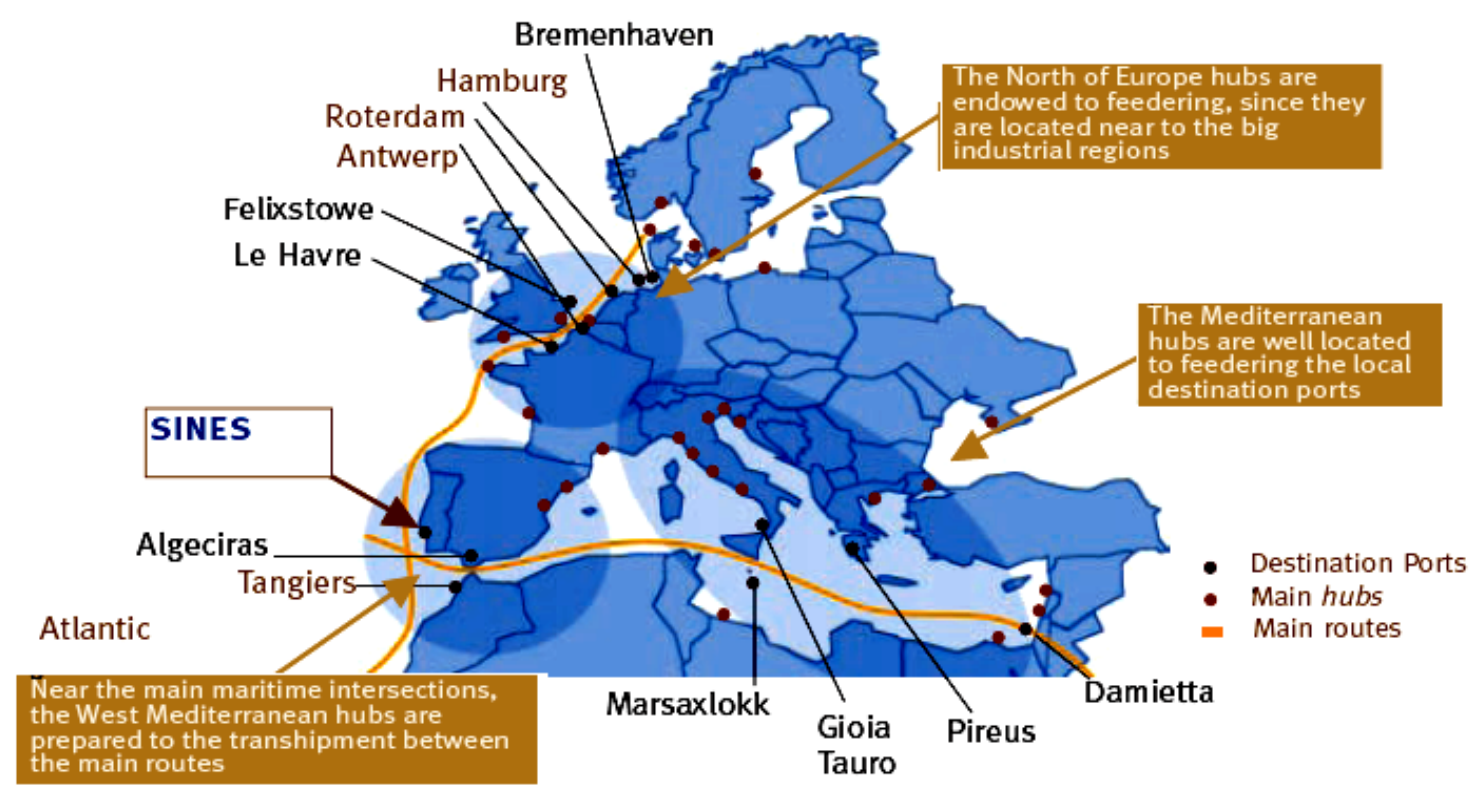

Source: Drewy; Analysis of the Project Team

Fig. 3 Maritime accessibility of the Port of Sines

Data source: Port of Sines strategic plan (2003, p. 33). 
As concerns land accessibility, both the Port of Sines and the Industrial and Logistics Zone offer excellent road and rail connections, directly linked to the terminals and the industry settled, thus providing a prompt response to present traffic. In order to give a proper answer to the Port's strategic objective in terms of cargo handling (to double the volume of cargo handled until 2015), a plan is already under implementation, which will provide, suitable links to both Portuguese and Spanish hinterland (IC33-Sines/Évora/Spain; IP8- Sines/Beja/Spain; and rail connection Sines/Elvas/Spain). Hinterland Connections are a vital part of the transport chain for the Port of Sines, which handles a wide variety of goods in transit between Iberia, southern Europe and key places around the world. For transport operators, one of the big advantages of Sines is easy access to the Port for both road and rail traffic. All the main terminals are linked by a modern road system to the national highway network.

Road links between Sines and the hinterland were upgraded to allow goods traffic to flow more quickly and easily since it has no problems with road congestion. Trucks can move freely between the ship terminals and the main highway system at all times of the day. The rail link between Sines and Madrid and other European capitals is to be improved. The nearest major airport to Sines is Lisbon, but in addition there is a regional airport facility at Beja, where a civil zone has been established at the military air base.

\subsubsection{Port operations}

The Port of Sines operates 24 hours a day, all year round. Vessels and cargoes are offered permanent services, such as: Vessel Traffic System (VTS), pilotage, towage and mooring, access control and surveillance; fresh water and bunkers, accidents/pollution fighting, ship repair (land and onboard). The development of the quality management system is an important contribution to entrepreneur's innovation processes by valuing the client. Quality management in the Port system, seen as a differentiation factor towards competitive Ports and other means of transport, in particular by road, aims for the service constant improvement paying attention to the integration of other fundamental aspects: Environment (ISO 14001), Safety (OHSAS 18001) and Safety in Information Technologies (ISO 27001).

Although loading and unloading containers is the key operation in shaping the success of a Port, there are a number of support features or enablers that make the Port operations highly effective and help sustain its competitive advantage; such as the vessel's traffic, and the value added services offered (Gordon, et al., 2005). The general shipment presented a significant increase relatively to $2005(119,70 \%)$, due to the addition of the movement of shipment in containers in the Port of Sines which registered a total of 1.473 .493 ton., corresponding to 121,956 TEU's, 85,278 containers (Fig. 4).

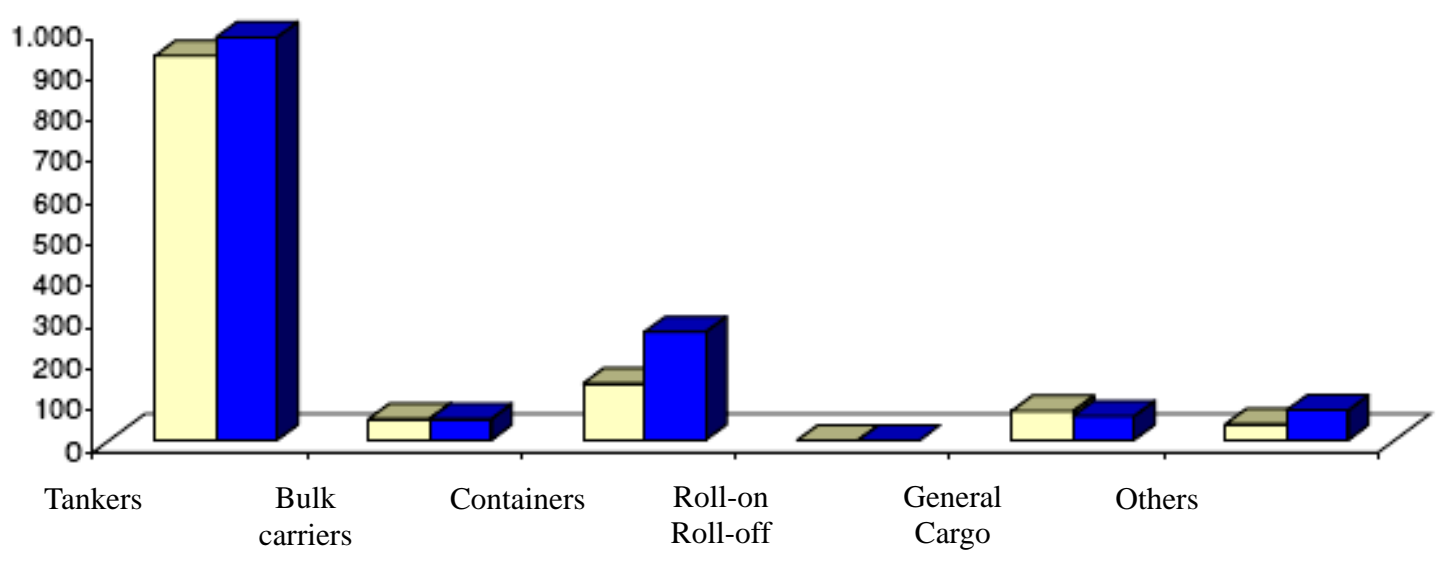

Fig. 4 Type of vessel

Data source: Statistics Report (2006). 
With respect to the value added services, the Port of Sines operates 24 hours a day, all year round. Port of Sines attempts to provide valued added services to its traditional Port operations. So beyond the ones related with the approaches and inward, it can offers the followings: (i) communications in Port navigation; (ii) bunkers provisions and other goods supply to vessels; (iii) vessels and boats repair; iv) wastes integrated management; (v) Vessel Traffic System (VTS); (vi) pilotage towage and mooring; (vii) access control and surveillance; (viii) fresh water and bunkers; (ix) accidents/pollution fighting; and (x) ship repair (land and onboard).

\subsubsection{The information systems as a key resource}

Growing number of organisations are under pressure from their partners to change their traditional management style, both operationally and organizationally, replacing them with integrated systems that help increase the speed and fluidity of physical and information flows. In order to reach this kind of integration they are investing on new information systems supported by important Information and Communication Technologies (ICT). Information systems are defined as the people, equipment, and procedures used to gather, sort, analyze, evaluate, and distribute needed, timely and accurate information to decision makers (Murphy \& Wood, 2004). In the knowledge-based economy, the rapidly changing and uncertain environment makes organisations face the biggest challenge that how to break the current situations and to capture their competitive advantage. The works of Parsons (1983), Porter and Millar (1965), Porter (1985), Constanza and Cynthia (1993) and McGaughey, et al (1994) pointed out the importance of the information systems, in the determination of the organisations' competitive advantage. Information systems force organizations to find new ways to expand the markets in which they compete, to attract and retain customers by customizing products and services, and to restructure their strategy to obtain competitive advantage (Gratzner \& Winiwarter, 2003).

The information systems are very important also to the Ports operations and represent a vital link in the logistics chain since ports act as information distribution centres to all the players that participate in the ports' activities (Marlow \& Casaca, 2003). The Port of Sines is using information systems to provide information about movement and clearance of vessels and cargoes. These systems link public and private organisations which need to be able to access information about intermodal movement of cargo, nationally and internationally. It makes use of the One Stop Shop concept, widely regarded as an improved system because it allows the participants to interact with all the available cargo and vessel handling services through a single channel of communication. The One Stop Shop is very useful for electronic customs clearance, since it provides a quicker clearance of vessels and cargoes, along with more efficient processing of tax requirements. The One Stop Shop is currently being integrated with the information systems used by logistics operators in connection.

The Port of Sines is using also an Enterprise Resource Planning (ERP) system to support its day-to-day operations in areas such as finance, maintenance, human resources, contracts, and projects management. The Port has also developed a Data Warehouse to manage all information concerning analysis and statistics, as well as providing a decision support database. The use of these information systems and according to Daugherty, Ellinger and Rogers (1995) allow the organizations in general to reach a superior performance. This is because the use of information systems becomes organizations more responsive and agile contributing to enhance the customers' fulfilment.

The Port of Sines uses some information systems such as: intranet, extranet and Single Port Window. We would like to highlight the use of the single Port window named Portmos. The Portmos is a platform designed and created to support the motorway of the sea services, providing global door-to-door integration and visibility over the entire transport and logistic chain. The Portmos platform integrates information and provides seamless 
communication between all the actors in the transport chain, without replacing their information systems. This platform supports: door-to-door tracking, integrated transport chain management, online booking of intermodal services, transport chain monitoring and benchmarking, including Service Performance Indicators.

\subsection{Key performance data}

Port performance in a worldwide context has been measured in terms of Teus (20-foot equivalent units) or cargo volume in tons (Marlow \& Casaca, 2003). In general the Port of Sines presents a positive performance evolution. As regards the cargo handling and as can be seen in Fig. 5 it is facing an important improvement principally from the year 2000. In the year of 2006 the improvement was yet more visible since this performance measure reach the value of 27,196,330 tons which represents an increase about $8.61 \%$ comparing with the year of 2005.

The cargo handling in 2006 represented the best mark since the start-up stage of the Port. With reference to the liquid bulks in the Port of Sines, in the year 2006, were handling 19,506,184 tons, which represents an increase of 5.14\% regarding 2005 and of $72 \%$ over all the cargo handling on it. As regards the general cargo, it had a significative increase on about $119.70 \%$ comparing to 2005 . This is due mainly to the increase on cargo container which reach a total of 1,473,496 tons and 121,956 TEUs.

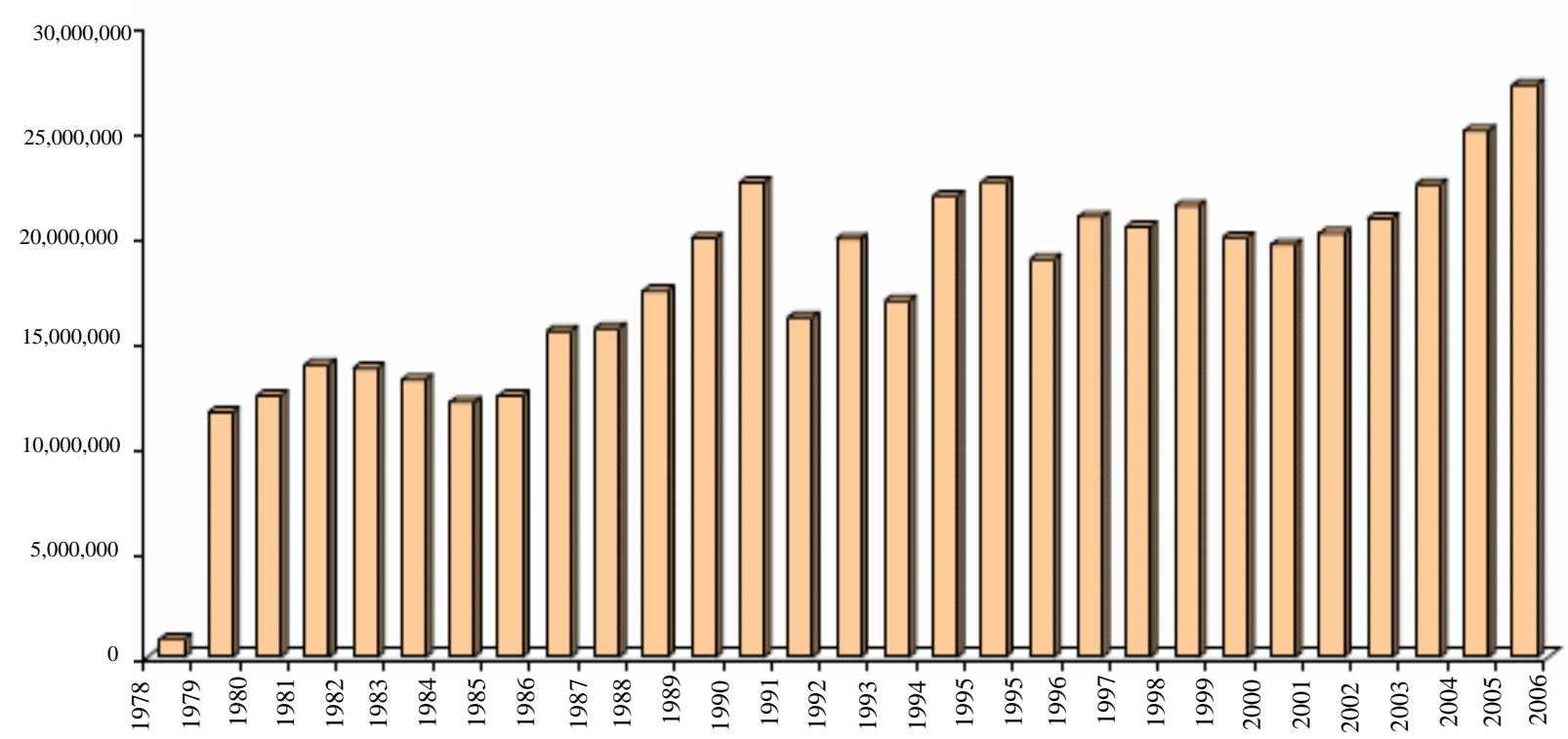

Fig. 5 Cargo handling (Tons) (1978-2006)

Data source: http://www.Portodesines.pt/pls/Portal/go (acedido em 18/1/2008).

As regards the cargo' type handling, deserves a special highlight the general container cargo since it had the greater increase from 2005 to 2006. More precisely it increased 281.44\% from/to Portugal; 73.96\% from/to European Union and $337.81 \%$ from/to third countries ${ }^{1}$. Considering the vessel's traffic, this performance indicator has increase during the last six years. In the year of 2006 its value was very good, more than 1400 vessels goes to the Port of Sines (Fig. 6).

\footnotetext{
${ }^{1}$ http://www.Portodesines.pt/pls/Portal/go acedido em 18/1/2008.
} 


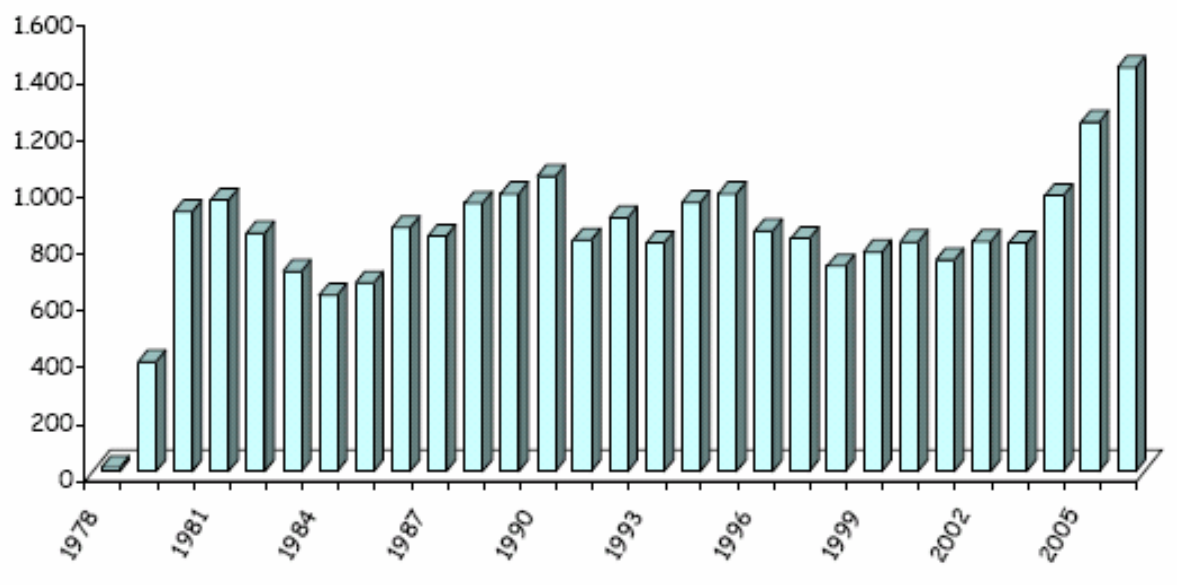

Fig. 6 Vessel’s traffic (1978-2006)

Data source: Statistics Report (2006).

Table 1 Main nationalities of the vessels that use the Port of Sines

\begin{tabular}{lrrr}
\hline \multirow{2}{*}{ Flag } & \multicolumn{2}{c}{ Number of vessels } & Var. \% \\
\cline { 2 - 3 } & 2005 & 2006 & 15.52 \\
\hline Total & 1231 & 1422 & 15.52 \\
Nationals & 268 & 285 & 18.07 \\
Foreigns & 963 & 1137 & -17.78 \\
Chipre & 45 & 37 & 4.41 \\
Spain & 68 & 71 & -32.65 \\
Netherland & 49 & 33 & 69.23 \\
Bahamas Islands & 39 & 66 & -2.78 \\
Marshall Islands & 36 & 35 & 13.92 \\
Liberia & 79 & 90 & 15.75 \\
Malta & 146 & 169 & 55.48 \\
Panama & 155 & 241 & 52.27 \\
United Kingdom & 44 & 67 & 0 \\
Singapore & 39 & 39 & \\
\hline
\end{tabular}

Data source: Adapted from Statistics Official Report, 2006.

The Port of Sines has an important role to the global economy given that there are many vessels that comes to and goes from the Port of Sines to around the world. As can be seen in the Table 1, in general the number of vessels that use the Port of Sines increased. From 2005 to 2006 this indicator grows 15.52\% contributing to it mostly the foreign vessels. The most of the vessels that use the Port of Sines comes from Panama, Malta, Liberia and Spain. From 2005 to 2006 the most increase in the number of vessels comes from Bahamas Islands (69.23\%).

\section{Conceptual model proposed}

After analysing the several features about the Port of Sines and its main resources, we propose a conceptual 
model to illustrate and justify why this Port could be considered as competitive (Fig. 7).

As can be seen in Fig. 7 the main resources and capabilities which contribute to enhance the competitiveness of the Port of Sines are the ones related with Port operations, accessibilities, information systems and also infrastructures. This resources and capabilities are considered Value, Rare, Inimitable and organisation allowing the Port of Sines to attain a superior performance and consequently a better competitive position.

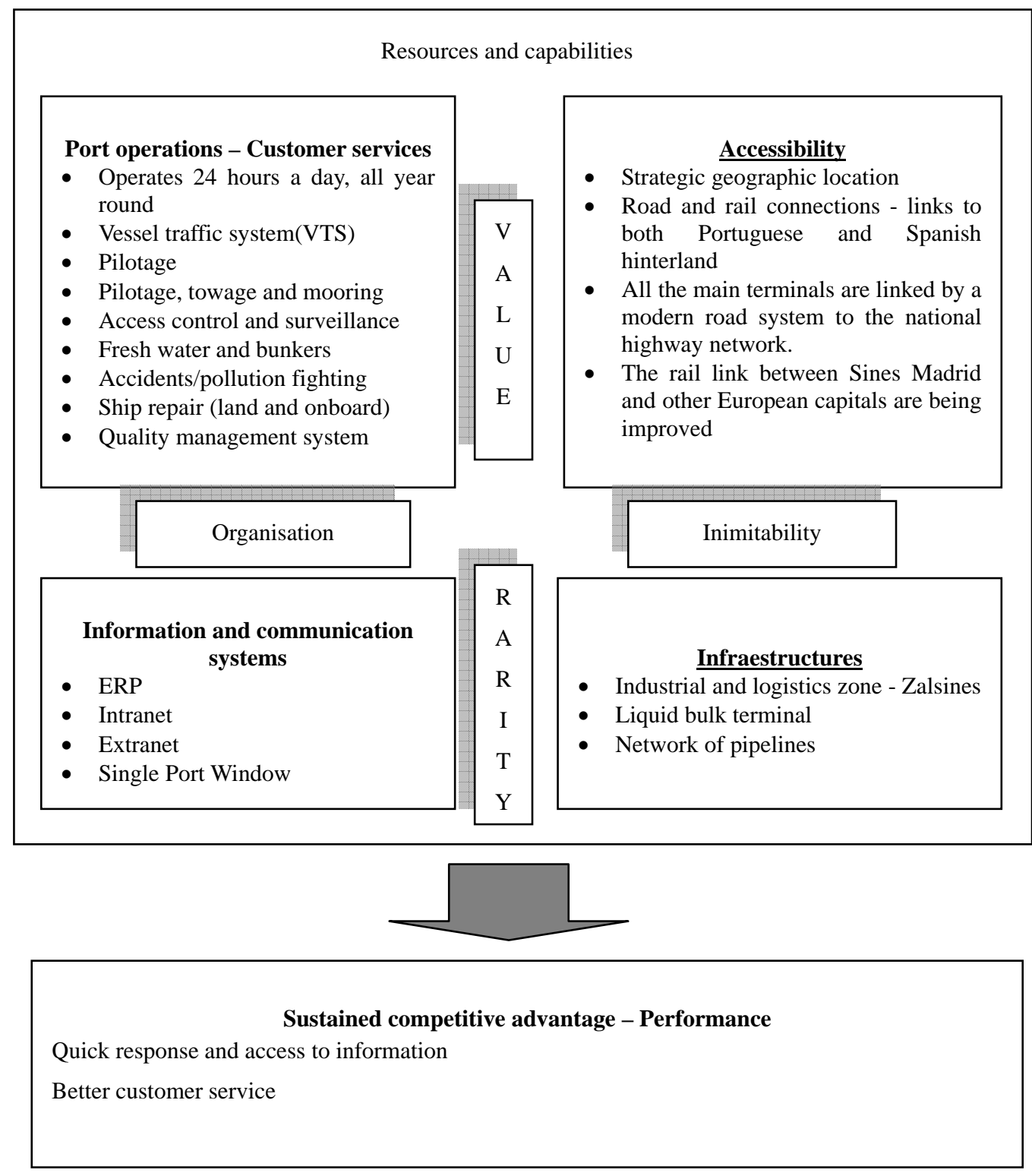

Fig. 7 Conceptual model proposed

\section{Conclusions}

Understanding sources of sustained competitive advantage for firms has become a major area of research in the field of strategic management. One source of sustained competitive advantage which is very followed by academics is the firms' resources and capabilities that is the Resource-Based view. 
According to this theory for a firm to take high levels of performance and a sustained competitive advantage, it needs to acquire heterogeneous resources which will be difficult to create, to substitute or to imitate by other firms. The firms reach a superior performance, not only because they have more or better resources, but also because of their distinctive competences allow to do better use of them. We analysed the main resources and capabilities of the Port of Sines enhancing its principal characteristics in an effort to understand the factors that justify its success and international competitiveness. The main resources analysed are: (i) the Port operations from the point of view of customer service; (ii) the road and rail accessibilities; (iii) the information and communication systems used to increase the customer service; and (iv) the main infrastructures in terms of terminals, and to support the industrial and logistics activities.

The value, rare, inimitable and organized resources of the Port of Sines contribute to built on strong capabilities and consequently to attain superior performance and competitive advantage. Through its superior resources the Port of Sines can offer a quick response and a better access to information, a superior customer service and also a better processing and faster communication between the entities involved in Port operations.

\section{References:}

Aliouat B. (1996). Les stratégies de coopération industrielle. Economica, 226-252.

Amit, R. \& Schoemaker, P. (1993). Strategic assets and organizational rent. Strategic Management Journal, 14, 33-46.

Barney, J. (1991). Firm resources and sustained competitive advantage. Journal of Management, 17, 99-120.

Barney, J. (1986). Strategic factor markets: Expectations luck and business strategy. Management Science, 42, 1231-1241.

Bogaert, I., Maertens, R. \& Van Cauwenbergh, A. (1994). Strategy as a situational puzzle: The first of components. In: Hamel, G. \& Heene, A. (Eds.). Chichester: Competence-Based Competition, John Wiley.

Chandler, G. \& Hanks, S. (1994). Market attractiveness resource-based capabilities, venture strategies and venture performance. Journal of Business Venturing, 9, 331-349.

Constanza, H. \& Cynthia, M. (1993). Strategic information systems and competitiveness: Are firms ready for an IST-driven competitive challenge? Information \& Management, 25, 183-193.

Daugherty, Patricia, Sabath, Robert, Dale \& Rogers. (1992). Competitive advantage through customer responsiveness. Logistics and Transportation Review, 28(3), 257-265.

Day, G. \& Wensley, R.. (1988). Assessing advantage: A framework for diagnosing competitive superiority. Journal of Marketing, 52, 17-32.

Day, G. (1994). The capabilities of market-driven organizations. Journal of Marketing, 58(4), 37-52.

Dierickx, I. \& Cool, K.. (1990). A resource-based perspective on competition strategy, Mimeo, INSEAD.

Gordon, J., Lee, P-M. \& Lucas, Jr. H.. (2005). A resource-based view of competitive advantage at the Port of Singapore. Journal of Strategic Information Systems, 14, 69-86.

Granstrand, O., Patel, P. \& Pavitt, K.. (1997). Multi-technology corporations: Why they have distributed rather than distinctive core competencies. California Management Review, 39(4), 8-25.

Grant, R. M.. (1991, Spring). The resources-based theory of competitive advantage: Implications for strategy formulation. California Management Review, 114-135.

Gratzer, M \& Winiwarter, W.. (2003). Proceedings of the 10th International Conference On Information Technology And Travel \& Tourism. Berlin: Springer - Verlag.

Greene, P., Brush, C. \& Brown, T.. (1997). Resources in small firms: An exploratory study. Journal of Small Business Strategy, 8(2), 25-40.

Hall, R.. (1997). The strategic analysis of intangible resources. Strategic Management Journal, 13(1), 135-144.

Hitt, M. \& Ireland, D.. (1986). Relationships among corporate level distinctive competencies, diversification strategy, corporate strategy and performance. Journal of Management Studies, 23, 401-416.

Itami, H.. (1987). Mobilizing invisible assets. Boston: Harvard University Press.

Jacobsen, R.. (1988). The persistence of abnormal returns. Strategic Management Journal, 9, 41-58. 
Learned, E., Christense, C., Andrews, K. \& Guth, W.. (1969). Business policy. Homewood, IL: Irwin.

Leonard-Barton, D.. (1992). Core capabilities and core rigidities: A paradox in managing new product development. Strategic Management Journal, 13, 111-125.

Lippman, S. \& Rumelt, R.. (1982). Uncertain imitability: An analysis of interfirm differences in efficiency under competition. Bell Journal of Economics, 13, 418-438.

Mahoney, J. \& Pandian, J.. (1992). The resource-based view within the conversation of strategic management. Strategic Management Journal, 33, 363-380.

Marlow, P. \& Casaca, A.. (2003). Measuring lean ports performance. International Journal of Transport Management, 1(4), $189-202$.

McGaughey, R., Snyder, C. \& Carr. H.. (1994). Implementing information technology for competitive advantage: Risk management issues. Information and Management, 26(5), 273-281.

Miller, D. \& Shamsie, J.. (1996). The resources-based view of the firm in two environments: The Hollywood film studios from 1936 to 1965. Academy of Management Journal, 39(3), 519-543.

Murphy, P. \& Wood D.. (2004). Contemporary logistics (8th ed.). Upper Saddle River, NJ: Prentice-Hall.

Nelson, R.. (1991). Why do firms differ and how does it matter? Strategic Management Journal, 14(3), 179-192.

Olavarrieta, S. \& Ellinger, A.. (1997). Resource-based theory and strategic logistics research. International Journal of Physical Distribution and Logistics Management, 27(9/10), 559-587.

Parsons, G... (1983, Fall). Information technology: A new competitive weapon. Sloan Management Review, 3-14.

Penrose, E.. (1959). The theory of the growth of the firm. Oxford: Basil Blackwell.

Peteraf, M.. (1993). The cornerstone of competitive advantage: A resource-based view. Strategic Management Journal, 14, 179-191.

Porter, M. \& Millar, V.. (1985). How information gives you competitive advantage. Harvard Business Review, 63(4), 49-160.

Porter, M.. (1985). Competitive advantage. New York: Free Press.

Prahalad, C. \& Hamel, G.. (1990, May-June). The core competence of the corporation. Harvard Business Review, 68, 79-91.

Rumelt, R.. (1991). How much does industry mater? Strategic Management Journal, 12(3), 167-185.

Schulze, W.. (1994). The two schools of thought in resource-based theory: Definitions and implications for research. In: Shrivastava, P. \& Dutton, J.. (Eds.). Advances in strategic management (Vol. 10), Press Greenwich.

Skjoett-Larsen, T.. (2000). European logistics beyond 2000. International Journal of Physical Distribution and Logistics Management, 30(5), 377-387.

Teece, D. \& Pisano, G... (1994). The dynamic capabilities of firms: An introduction, the political economy of science, technology and innovation. Oxford University Press.

Tongzon, J.. (2007). Determinants of competitiveness in logistics: Implications for the Asean region. Maritime Economics \& Logistics, 9, 67-83.

Wernerfelt, B.. (1989). From critical resources to corporate strategy. Journal of General Management, 14, 4-12.

(Edited by Joy and Chris) 